\title{
Exploring the Role of Selected Bacterial Strains in Chromium (Cr(Vi) Reduction from Soil
}

\author{
Rachna Singh ${ }^{1}$ and Mahendra K. Gupta ${ }^{2^{*}}$ \\ ${ }^{1}$ School of Studies in Microbiology, Jiwaji University, Gwalior, India \\ ${ }^{2}$ School of Studies in Botany, Jiwaji University, Gwalior, India \\ *corresponding author: mkgsac@yahoo.com, (09425158048)
}

Available online at: www.isroset.org

Received: 21/Jan/2019, Accepted: 06/Feb/2019, Online: 28/Feb/2019

\begin{abstract}
World's rapidly evolving population and its progressive attraction towards luxurious life has unsurprisingly led to an increase in anthropogenic sources of pollution. Environmental contamination of hexavalent chromium Cr(VI) is of serious concern for its toxicity as well as mutagenic and carcinogenic effects. Bacterial chromate reduction is a cost-effective technology for detoxification and removal of $\mathrm{Cr}(\mathrm{VI})$ from polluted environment. In current study, a total of $15 \mathrm{Cr}(\mathrm{VI}) \mathrm{resistant}$ bacterial isolates were isolated after enrichment at three different $\mathrm{Cr}(\mathrm{VI})$ concentrations- $25 \mathrm{mg} / \mathrm{L}, 50 \mathrm{mg} / \mathrm{L}$ and $100 \mathrm{mg} / \mathrm{L}$. Out of 15 only three- S1B, S10D and S3-A with a maximum tolerance of $100 \mathrm{mg} / \mathrm{L} \mathrm{Cr}$ (VI) concentration were selected for further study. On the basis of biochemical characterization isolates were identified, S1-B as Enterococcus faecalis, S10-D as Bacillus megaterium and S3-A as Bacillus cereus. Efficiency of chromium reduction by selected isolates was evaluated at optimized growth conditions. All the three isolates have shown excellent chromium reduction with $100 \%$ by S10D, $78.6 \%$ by S1B and $61.36 \%$ by S3-A at $25 \mathrm{mg} / \mathrm{L}$ of $\mathrm{Cr}(\mathrm{VI})$ concentration. All three isolates had shown around $60 \%$ reduction within $48 \mathrm{~h}$ of incubation period. Multimetal resistance was also determined against six different heavy metals ( $\mathrm{Hg}, \mathrm{Cd}, \mathrm{Pb}, \mathrm{Zn}, \mathrm{Co}, \mathrm{Mn})$. $\mathrm{Cd}$ and $\mathrm{Hg}$ were highly toxic and supressed the bacterial growth completely, only S10D was resistant to Cd. S2D, S3A and S10D were resistant against $\mathrm{Co}, \mathrm{Pb}$ and $\mathrm{Mn}$ while growth of $\mathrm{S} 3 \mathrm{~A}$ was inhibited by $\mathrm{Zn}$. These potential bacterial isolates could be used at industrial level for effluent treatment and also have great significance for bioremediation of chromium contaminated sites.
\end{abstract}

Keywords: Anthropogenic, bioremediation, carcinogenic, degradation potential, multimetal resistance

\section{INTRODUCTION}

Heavy metals are persistent and very rarely biodegradable. To combat heavy metal pollution, extensive research is going on advanced technologies for removal of heavy metals, other toxic contaminants from industrial wastewater. Their toxicity, especially in high concentrations, has become a global issue [1]. The term "heavy metals" refers to any metallic element that has a relatively high density $>5 \mathrm{~g} / \mathrm{cm}^{3}$ and is toxic or poisonous even at low concentration. Most common heavy metals present in industrial wastes are chromium, copper, cadmium, nickel and mercury. Chromium is the seventh most abundant element on earth and exists in several oxidation states. Main sources of $\mathrm{Cr}(\mathrm{VI})$ release in the effluent are electroplating industries, tannery industries, leather industries textile and ceramics. Chromium primarily exists in two stable oxidation states of $\mathrm{Cr}$ (III) and $\mathrm{Cr}(\mathrm{VI})[2]$, which have contrasting toxicities, mobility and bio-availabilities. In the last few decades, the amount of chromium in both aquatic and terrestrial ecosystems has increased as a consequence of anthropogenic activities $[3,4]$. It is now considered as one of the major environmental pollutants due to its toxicity for ecological, nutritional and environmental reasons. The discharge of waste water and other material from different industrial resources containing heavy metals have resulted in an increased population of the resistant bacteria. Therefore, these bacteria can be used as potential tools for bioremediation. The advantage of selecting indigenous bacteria from contaminated environments may be the minimization of inhibitory effects from other compounds that may result in present along with $\mathrm{Cr}(\mathrm{VI})$, as viable indigenous organisms will have developed some degree of resistance to these compounds [5]. Microorganisms and microbial products have been reported to efficiently remove soluble and particulate forms of metals, especially from dilute solutions. There are different mechanisms like 
bioaccumulation, adsorption and reduction etc. therefore microbe-based technologies provide an alternative to the conventional techniques of metal removal or recovery [6]. Considering the metal threat to microbes, plants and consequently to human health and realising the biosorbing ability of microbes, the current study is aimed with isolation of efficient chromium resistant indigenous bacterial isolates that could be significant to be used in bioremediation effectively. For this screening of chromium resistant isolates for maximum tolerance level (MTL) was done and isolates having maximum resistance up to $100 \mathrm{mg} / \mathrm{L} \mathrm{Cr}(\mathrm{VI})$ concentration were selected for further study. Then biochemical characterization of selected bacterial isolates was done. Finally, chromium reduction study was performed by each isolate at optimized $\mathrm{pH}$, temperature, inoculum level and initial chromium concentration values in Nutrient broth. Furthermore the multimetal resistance of the selected isolates was also evaluated as it is very important trait for survival of bacteria in contaminated site.

\section{MATERIALS AND METHODS}

\section{Sample collection-}

Soil samples were collected from different industrial sites in Gwalior, MP, India, by using standard methods [7]. Immediately soil samples were taken to the lab under $4^{\circ} \mathrm{C}$ for further analysis.

\section{Enrichment-}

The enrichment of indigenous bacteria is carried out under aerobic conditions by modified method given by Joutey et al., [8] $1.0 \mathrm{~g}$ soil samples were mixed with $50 \mathrm{~mL}$ of sterile nutrient broth having $25 \mathrm{mg} / \mathrm{l} \mathrm{Cr}(\mathrm{VI})$ concentration and incubated at $37^{\circ} \mathrm{C}$ at $120 \mathrm{rpm}$ for $24 \mathrm{~h}$ using shaker incubator. After $24 \mathrm{~h}$ of incubation, $1 \mathrm{~mL}$ of each suspension was transferred to $50 \mathrm{~mL}$ of fresh medium amended with $50 \mathrm{mg} / \mathrm{L} \mathrm{Cr}(\mathrm{VI})$ and finally with $100 \mathrm{mg} / \mathrm{L}$ $\mathrm{Cr}(\mathrm{VI})$. Residual chromium concentration was determined at regular time intervals from culture supernatant at $540 \mathrm{~nm}$ spectrophotometrically (Shimadzu UV-1800) by diphenylcarbazide (DPC) method.

\section{Isolation-}

For isolation, enrichment culture was serially diluted, plated on nutrient agar medium $(10 \mathrm{mg} / \mathrm{L}$ of $\mathrm{Cr}(\mathrm{VI})$ and incubated for $48 \mathrm{~h}$ at $37^{\circ} \mathrm{C}$ [9]. Colonies were transferred thrice on similar medium and are subjected for further $\mathrm{Cr}(\mathrm{VI})$ reduction activity. Following three sequential transfers in increasing concentrations of chromium, the isolates were stocked in nutrient agar slants amended with $10 \mathrm{mg} / \mathrm{L}$ of $\mathrm{Cr}(\mathrm{VI})$, at $4^{\circ} \mathrm{C}$ until use.

\section{Screening of bacterial isolates for Maximum Tolerance Level (MTL)-}

The ability of the bacterial strains to grow under increasing concentrations of chromium was tested by solid agar plate modified method by Malik and Jaiswal [10]. To determine maximum tolerance, bacterial isolates were aseptically streaked on nutrient agar plates supplemented with 25, 50, 75 and $100 \mathrm{mg} / \mathrm{L}$ of $\mathrm{Cr}(\mathrm{VI})$ concentrations respectively. The highest concentration of metal supporting bacterial growth was defined as the maximum tolerance level (MTL).

\section{Morphological and biochemical characterization of selected bacterial isolates-}

For tentative identification bacterial isolates showing the highest MTL values were characterized morphologically and biochemically as per the Bergy's manual of Systematic Bacteriology [11]. Morphological study included- Grams staining, endospore staining and motility test. Colony characteristics were also observed. For biochemical characterization sugar fermentation test, IMVC (Indole, methyl red, voges proskauer and citrate), catalase, oxidase, amylase, urease, gelatinase, bile esculin, growth in $6.5 \%$ $\mathrm{NaCl}$ and nitrate reduction tests were performed.

\section{Optimization of different parameters-}

Bacterial growth is affected by several parameters like $\mathrm{pH}$, temperature, initial $\mathrm{Cr}(\mathrm{VI})$ concentration and inoculum level. Chromium reduction is directly proportional to growth of bacteria. So, optimization of above parameters was done with reference of bacterial growth. For all experiments fresh overnight grown bacterial cultures were used as inoculum at $1 \%$ inoculum value. For $\mathrm{pH}$, bacterial culture was inoculated into $50 \mathrm{~mL}$ of nutrient broth $(25$ $\mathrm{mg} / \mathrm{L} \mathrm{Cr}(\mathrm{VI})$ ) having different $\mathrm{pH}$ values from 2 to 10 by using dilute $\mathrm{HCl}$ or $\mathrm{NaOH}$. The influence of temperature on growth was determined by incubating inoculated broth at different temperatures $\left(30,35,40\right.$ and $\left.45^{\circ} \mathrm{C}\right)$. For determination of optimum initial inoculum level, bacterial cultures at- $1 \%, 2 \%$ and $3 \%$ different inoculum levels were inoculated in $50 \mathrm{ml}$ nutrient broth having $25 \mathrm{mg} / \mathrm{L}$ of $\mathrm{Cr}(\mathrm{VI})$ concentration. To evaluate the effect of the initial $\mathrm{Cr}(\mathrm{VI})$ concentration, bacterial culture was inoculated in 50 $\mathrm{ml}$ nutrient broth having different initial chromium concentrations of 50, 75, 100 and $125 \mathrm{mg} / \mathrm{L}$. All sets were incubated in shaker incubator at 120rpm for 72h (REMICLS24 plus). Bacterial growth was measured in terms of optical density at regular time intervals at $600 \mathrm{~nm}$ spectrophotometrically (Shimadzu UV-1800).

\section{Chromium reduction study by selected bacterial isolates-}

$\mathrm{Cr}(\mathrm{VI})$ reduction study was carried out under aerobic conditions for efficient bacterial isolates at optimized values of $\mathrm{pH}$, temperature, initial inoculum level and initial chromium concentration. Nutrient broth was inoculated with fresh overnight grown cultures of selected bacterial isolates. Cell growth was monitored by measuring the optical density at $600 \mathrm{~nm}$ at regular time intervals. 
Determination of residual $\mathrm{Cr}(\mathrm{VI})$ in culture supernatant was done at 540nm following diphenylcarbazide method.

\section{Determination of multi metal resistance-}

Resistance of bacterial isolates against six different heavy metals $\left(\mathrm{CO}^{+2}, \mathrm{Hg}^{+2}, \mathrm{~Pb}^{+2}, \mathrm{Cd}^{+2}, \mathrm{Zn}^{+2}\right.$ and $\left.\mathrm{Mn}^{+2}\right)$ was determined by inoculating bacterial isolates in nutrient broth having $50 \mathrm{mg} / \mathrm{L}$ concentration of different metals along with $25 \mathrm{mg} / \mathrm{L}$ concentration of chromium. The nutrient broth amended with $\mathrm{Cr}(\mathrm{VI})$ only was used as control. Resistance was determined as presence of bacterial growth and was measured in terms of optical density at regular time intervals at $600 \mathrm{~nm}$ spectrophotometrically.

\section{RESULTS AND DISCUSSION}

A total of 5 soil samples were collected from different metal contaminated sites at Gwalior and processed for $\mathrm{pH}$ and temperature determination. Soil sample enrichment was done at three $\mathrm{Cr}(\mathrm{VI})$ concentrations 25,50 and $100 \mathrm{mg} / \mathrm{L}$ in nutrient broth at $\mathrm{pH} 6.8,37^{\circ} \mathrm{C}$ and $120 \mathrm{rpm}$ for $72 \mathrm{~h}$ in orbital shaker incubator. Uninoculated control flasks were also kept at the same conditions.

From 5 soil samples, 15 bacterial isolates were obtained after serial dilution of enriched samples. Maximum tolerance level (MTL) of bacterial isolates was evaluated by streaking bacterial cultures on nutrient agar plate supplemented with different $\mathrm{Cr}(\mathrm{VI})$ concentrations-25, 50,
75 and $100 \mathrm{mg} / \mathrm{L}$ and visually compared for growth after 24 to $48 \mathrm{~h}$ incubation at $37^{\circ} \mathrm{C}$. A comparative percentage of bacterial isolates having resistance at different concentrations is presented in the pie chart (Fig.1). Out of 15 bacterial isolates, three isolates S1-B, S10-D and S3-A $(8 \%)$ had shown a good resistance at $100 \mathrm{mg} / \mathrm{L}$ chromium concentration and were selected for further study.

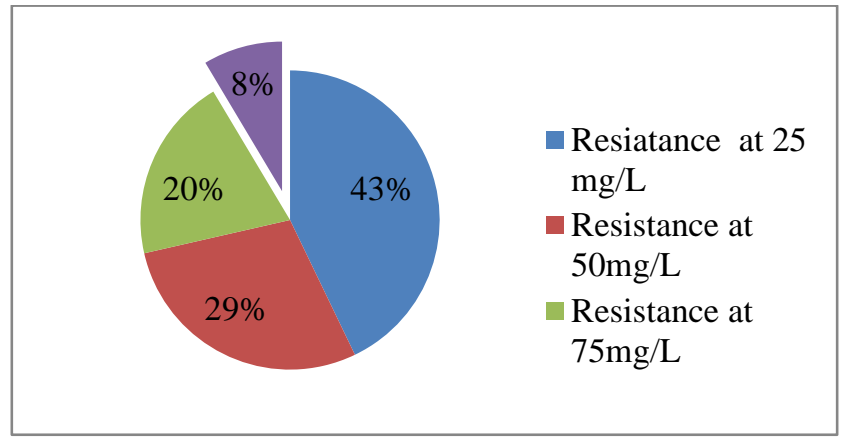

Fig. 1 Percentage of bacterial isolates having resistance at four different $\mathrm{Cr}(\mathrm{VI})$ concentrations.

On the basis of biochemical characterization bacterial isolates were identified as Enterococcus faecalis (S1-B), Bacillus megaterium (S10-D) and Bacillus cereus (S3-A). S1-B was positive for specific tests- Bile esculin and growth in $6.5 \% \mathrm{NaCl}$ (Table. 1 and 2).

Table 1 Morphological characteristics of selected bacterial isolates.

\begin{tabular}{|c|c|c|c|c|c|c|}
\hline $\begin{array}{l}\text { Name of } \\
\text { Isolates }\end{array}$ & Colony characteristics & $\begin{array}{l}\text { Gram } \\
\text { staining }\end{array}$ & Shape & Arrangement & Endospore & Motility \\
\hline S1-B & $\begin{array}{l}\text { Cream, punctiform, entire margin, } \\
\text { moist, opaque and flat, }\end{array}$ & $+\mathrm{ve}$ & Coccus & Cluster & Absent & Motile \\
\hline S10-D & $\begin{array}{l}\text { Cream, medium size, margin } \\
\text { fringes, glossy, opaque and flat }\end{array}$ & +ve & Rod & Streptobacillus & Present & - \\
\hline S3-A & $\begin{array}{l}\text { Cream, small, entire margin, } \\
\text { moist, transparent and raised }\end{array}$ & +ve & Rod & Streptobacillus & $\begin{array}{l}\text { Central } \\
\text { endospore }\end{array}$ & Motile \\
\hline
\end{tabular}

Table 2 Biochemical characterization of selected isolates

\begin{tabular}{llll}
\hline Biochemical tests & Bacterial isolates & & S3-A \\
\cline { 2 - 4 } & S1-B & - & - \\
\hline Indole & - & + & - \\
\hline Methyl red & + & - & - \\
\hline Voges proskauer & + & - & - \\
\hline Citrate utilization & - & + & + \\
\hline Catalase, Oxidase & - & + & + \\
\hline Amylase, Urease & - & & S \\
\hline
\end{tabular}




\begin{tabular}{|c|c|c|c|c|}
\hline \multicolumn{2}{|c|}{ Gelatinase } & - & - & - \\
\hline \multicolumn{2}{|c|}{ Nitrate reduction } & - & + & + \\
\hline \multicolumn{5}{|c|}{ Sugar fermentation test- } \\
\hline \multicolumn{2}{|c|}{ Lactose } & - & - & - \\
\hline \multicolumn{2}{|c|}{ Glucose } & + & + & + \\
\hline \multicolumn{2}{|c|}{ Maltose } & + & + & + \\
\hline \multicolumn{2}{|c|}{ Mannitol } & + & + & - \\
\hline \multicolumn{2}{|c|}{ Xylose } & + & - & - \\
\hline \multicolumn{2}{|c|}{ Arabinose } & + & + & + \\
\hline \multirow{3}{*}{$\begin{array}{l}\text { Triple } \\
\text { Sugar } \\
\text { Iron }\end{array}$} & Slant & $\mathrm{R} / \mathrm{R}$ & $\mathrm{R} / \mathrm{R}$ & $\mathrm{R} / \mathrm{R}$ \\
\hline & $\mathrm{H} 2 \mathrm{~S}$ & - & - & - \\
\hline & Gas & - & - & - \\
\hline \multicolumn{2}{|c|}{ Tentative identification } & Enterococcus faecalis & Bacillus megaterium & Bacillus cereus \\
\hline
\end{tabular}

$\mathrm{R} / \mathrm{R}$ - slant and butt both were red

For efficient chromium reduction optimization of different parameters- $\mathrm{pH}$, temperature, initial inoculum level and initial chromium concentration was performed for selected three bacterial isolates in nutrient broth at $25 \mathrm{mg} / \mathrm{L} \mathrm{Cr}$ (VI) concentration. Optimum $\mathrm{pH}$ values for isolates S1-B, S10-D and $\mathrm{S} 3-\mathrm{A}$ were $\mathrm{pH}$ 6.8, 10 and 8 respectively (Fig. 2). In the similar study by Joshi and Modi [12] has been reported that optimum $\mathrm{pH}$ for isolates SGPB1, PGNI2, PGCO3, KGCR4, PGMN6, SGZN7 was 7.5 while optimum $\mathrm{pH}$ for isolate PGCU5 was 6.5.

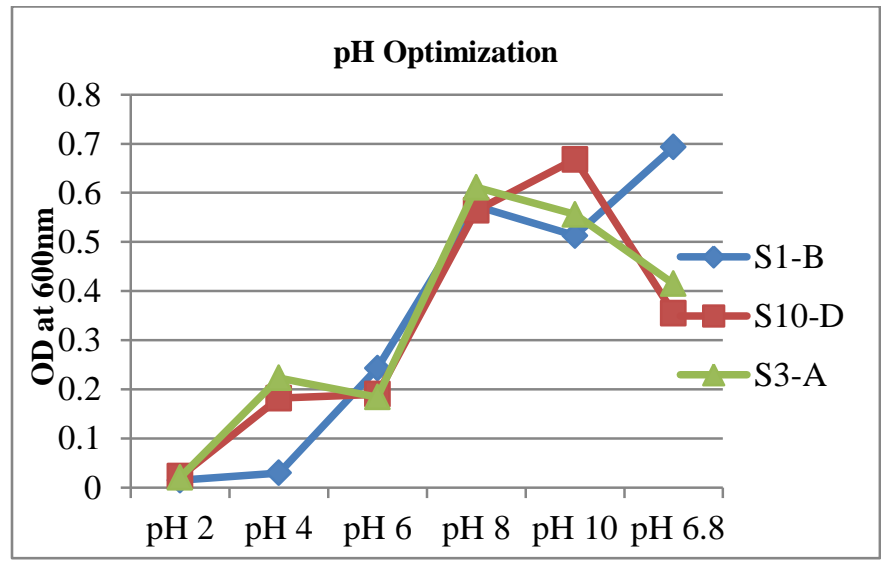

Fig. 2 Effect of $p H$ on the growth of selected bacterial isolates in nutrient broth with $25 \mathrm{mg} / \mathrm{L} \mathrm{Cr}$ (VI) at $37^{\circ} \mathrm{C}$ for $72 \mathrm{~h}$

Optimum temperature values for isolates $\mathrm{S} 1-\mathrm{B}$ and $\mathrm{S} 3-\mathrm{A}$ was $37^{\circ} \mathrm{C}$ while for $\mathrm{S} 10 \mathrm{D}$ it was $45^{\circ} \mathrm{C}$ (Fig.4). Optimum temperature for bacterial growth is reported $37^{\circ} \mathrm{C}$. So, two isolates are supporting this view. In another study by Liu et al., $\mathrm{Cr}$ (VI) reduction by the bacterium, XW-4, was evaluated under three different temperatures: 20, 37 and $47^{\circ} \mathrm{C}$. Similar result is reported that complete reduction was observed at $37^{\circ} \mathrm{C}$ after $72 \mathrm{~h}$ by Bacillus sp. (XW-4) isolated from chromium landfill site [13].

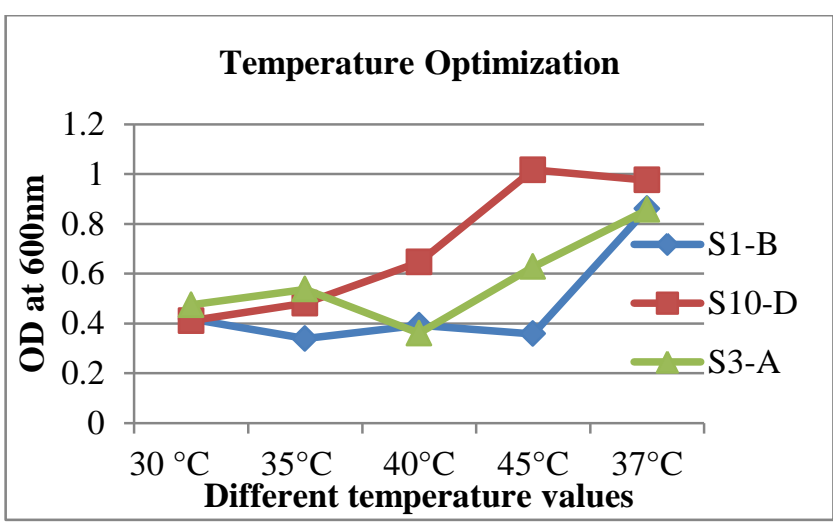

Fig. 3 Effect of temperature on growth of bacterial isolates in nutrient broth with $25 \mathrm{mg} / \mathrm{L} \mathrm{Cr}(\mathrm{VI}), \mathrm{pH}-6.8$ for $72 \mathrm{~h}$

Optimum inoculum values for isolates S1-B, S3-A and S10D was observed as $2 \%$ and $3 \%$ respectively (Fig.5). In another study, Biswas et al., had reported that Alcaligenes faecalis strain P-2 showed the optimum growth when medium contained $5 \%$ of inoculum [14].

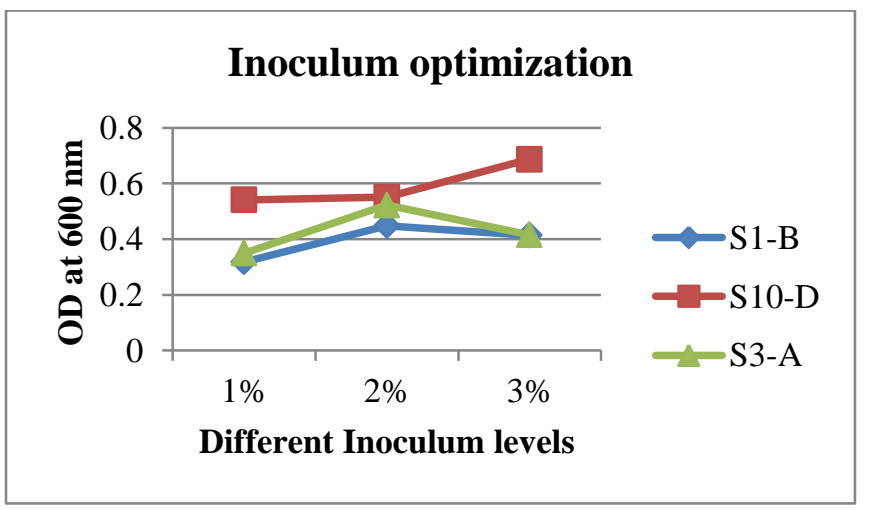

Fig. 4 Effect of inoculum levels on growth of bacterial isolates in nutrient broth with $25 \mathrm{mg} / \mathrm{L} \mathrm{Cr}(\mathrm{VI})$ at $37^{\circ} \mathrm{C}, \mathrm{pH}$ 6.8 for $72 \mathrm{~h}$ 
As represented in Fig.6, optimum initial chromium concentration value for isolates S1-B, S10-D and S3-A is 25 $\mathrm{mg} / \mathrm{L}$. Growth of isolates is decreasing with increase of $\mathrm{Cr}(\mathrm{VI})$ concentrations due to toxic effect of chromium but all the three isolates are showing resistance at $100 \mathrm{mg} / \mathrm{L}$ $\mathrm{Cr}$ (VI) concentration. Similarly, Biswas et al., has also reported that there was significant difference in the growth of the isolates at different concentration of chromium.

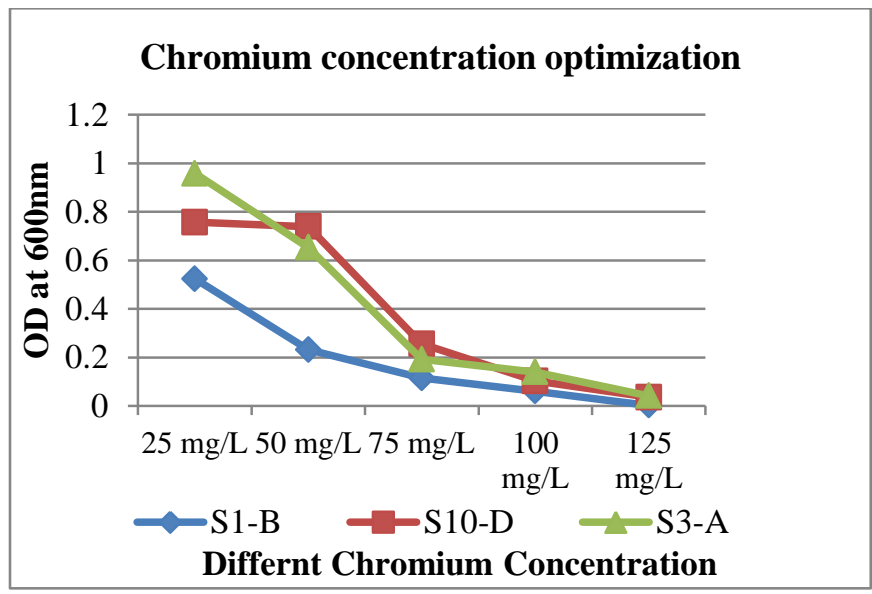

5 Effect of initial $\mathrm{Cr}(\mathrm{VI})$ concentrations on growth of selected bacterial isolates in nutrient broth at $37^{\circ} \mathrm{C}, \mathrm{pH} 6.8$ for $72 \mathrm{~h}$

Final chromium reduction study was performed at above optimized values. Residual chromium concentration was measured at regular time periods for $120 \mathrm{~h}$ by DPC method at 540nm spectrophotometrically. Percentage of chromium reduction by bacterial isolates was determined. As represented in Fig.7, all the three isolates showed a gradual chromium reduction with increasing time intervals. S1-B showed highest chromium reduction $(68 \%)$, while S10-D $(60 \%)$ and S3-A showed minimum chromium reduction among three $(53.36 \%)$ at $25 \mathrm{mg} / \mathrm{L} \mathrm{Cr}$ (VI) concentration. Similarly, Bakiyaraj et al., has reported that Bacillus sp. and Pseudomonas sp. removed 87\%, 73\%, 65\% and $60 \%$ chromium from medium in 48 hours starting with the initial concentration of $5 \mathrm{ppm} / \mathrm{L}, 10 \mathrm{ppm} / \mathrm{L}, 25 \mathrm{ppm} / \mathrm{L}$ and 50 $\mathrm{ppm} / \mathrm{L}$ respectively [15]. Similar work is reported by Basu et al., that Bacillus subtilis had shown $97 \%$ removal of chromium with an initial concentration of $2.5 \mathrm{mg} / \mathrm{L} \mathrm{[16].}$ Dey and Paul in their study revealed that three bacterial isolates, SUK 1201(Arthrobacter sp.), SUK 1205 (Arthrobacter sp.) and SUK 1207(Pseudomonas sp.) were able to reduce more than $50 \%$ and $80 \%$ of initial $2 \mathrm{mM} \mathrm{Cr}$ (VI) concentration [17].

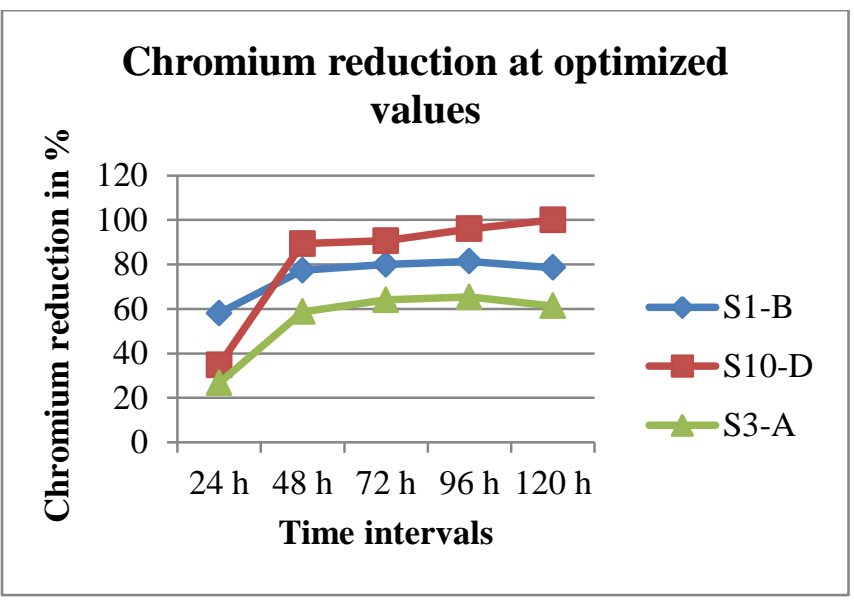

Fig. 6 Percentage reduction of $\mathrm{Cr}(\mathrm{VI})$ in nutrient broth at optimized values by bacterial isolates at optimized values for $120 \mathrm{~h}$

Multimetal resistance was determined against six heavy metals and all three isolates showed a different resistance pattern for different heavy metals. S10 D showed the maximum resistance against five metals and S3A, showed minimum against three. $\mathrm{Cd}^{+2}$ and $\mathrm{Hg}^{+2}$ were highly toxic, all three isolates were inhibited by $\mathrm{Cd}^{+2}$ and only $\mathrm{S} 10 \mathrm{D}$ was resistant against $\mathrm{Hg}^{+2}$. Cadmium $(\mathrm{Cd})$ is highly toxic, has a long biological half-life and causes the neurological disability in humans and animals by entering in brain parenchyma and neurons. That result in memory shortfalls, low concentration power etc. in humans [18]. Degree of sensitivity towards different heavy metals was as- $\mathrm{Cd}^{+2}>$ $\mathrm{Hg}^{+2}>\mathrm{Zn}^{+2}>\mathrm{Co}^{+2}>\mathrm{Pb}^{+2}>\mathrm{Mn}^{+2}$ (Fig.8). Similarly, U Thacker had also reported that Brucella sp. (DQ112027), showed multiple metal resistances to different levels. The degree of inhibition caused by tested metal cations was $\mathrm{Hg}^{+2}>\mathrm{Co}^{+2}>\mathrm{Cr}^{+6}>\mathrm{Ni}^{+2}>\mathrm{Pb}^{+2}>\mathrm{Zn}^{+2}$ [19]. In another study Sultan and Hasnain, have shown that gram positive chromate resistant isolate exhibited tolerance against salts of $\mathrm{Ba}^{+2}, \mathrm{Cd}^{+2}, \mathrm{Cu}^{+2}, \mathrm{Fe}^{+3}, \mathrm{Mn}^{+2}, \mathrm{Ni}^{+2}$ and $\mathrm{Pb}^{+2}$ but showed sensitivity to $\mathrm{Co}^{2+}, \mathrm{Hg}^{+2}$ and $\mathrm{Zn}^{+2}$ [20]. It is very important to determine the multimetal resistance as the contaminated site also had other toxic metals and compounds. It is a valuable trait for microbes to withstand in remediation study of the natural contaminated sites. Genes responsible for metal resistance are also associated for antibiotic resistance and are transferred among phylogenetically distant bacterial groups [21]. 


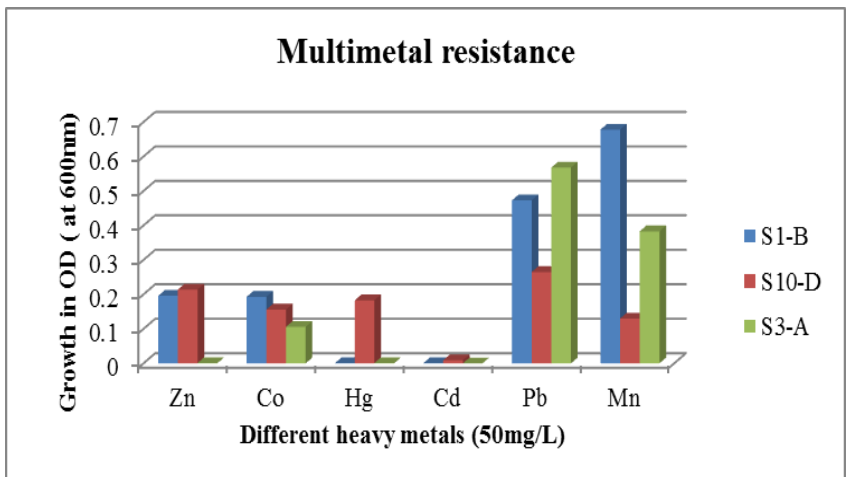

Fig.7 Determination of multimetal resistance by bacterial isolates for different heavy metals at $50 \mathrm{mg} / \mathrm{L}$ of concentration

\section{CONCLUSION}

Heavy metal toxicity is of great concern in the present scenario. To combat this toxicity attributed to these metals, there is an urgent need for an efficient industrial and domestic waste treatment strategy that eliminates priority pollutants at contaminated sites. These highly contaminated industrial sites have become the source of resistant microbes against different toxic heavy metals. The indigenous microorganisms can be used as an indicator of pollution and can be used to minimize the risk of public exposure to chromium contamination. In present research work three potent chromium reducing bacterial isolates with a significant chromium reduction efficiency, Enterococcus faecalis- (78.6\%), Bacillus megaterium- (100\%) and Bacillus cerus- $(61.36 \%)$ were isolated at $25 \mathrm{mg} / \mathrm{L}$ of $\mathrm{Cr}(\mathrm{VI})$ concentration and $37^{\circ} \mathrm{C}$. These isolates were found to exhibit multimetal resistance traits also for heavy metals such as $\mathrm{Hg}, \mathrm{Zn}, \mathrm{Co}, \mathrm{Pb}$ and $\mathrm{Mn}$, which opens a new path to use these isolates for bioremediation application. These isolates could be of great significance in finding a practical application in detoxification of chromium pollutants at industrial areas and is of great economic importance. Further research work to understand the mechanism of chromate reduction and evaluation of chromium reduction by preparing consortium is in progress.

\section{Acknowledgement}

Authors are thankful to Jiwaji University, Gwalior, MP, for financial support and School of studies in Microbiology, School of studies in Botany and Dr. APJ Abdul Kalam Central Instrumentation Lab, Jiwaji University, Gwalior for providing all working facilities.

\section{REFERENCES}

[1]. B.L. Martins, C.C.V. Cruz, A.S. Luna, C.A. Henriques, "Sorption and desorption of $\mathrm{Pb}+2$ ions by dead Sargassum sp. Biomass", Biochemical Engineering Journal, Vol. 27, pp. 310-314, 2006.
[2]. J. Chung, R. Nerenberg, B.E. Rittmann, "Bioreduction of soluble chromate using hydrogen based membrane bioflim reactor". Water Res. Vol. 40, pp. 1634-1642, 2006.

[3]. EPA, wastewater technology sheet: chemical precipitation. United State Environmental Protection, EPA 832F00018, 2000.

[4]. M.J. Horsfall, F. Ogban, E.E. Akporhonor, "Sorption of Chromium (VI) from Aqueous Solution by Cassava (Manihot Sculenta CRANZ) Waste Biomass". Chemistry and Biodiversity, Vol. 3, pp. 161-173, 2006.

[5]. T. Srinath, T. Verma, P.W. Ramteke, S.K. Garg,"Chromium (VI) biosorption and bioaccumulation by chromate resistant bacteria". Chemosphere, Vol. 48, pp. 427-435, 2002.

[6]. R. Branco, A.P. Chung, A. Verissimo, P.V. Morais, "Impact of chromium-contaminated wastewaters on the microbial community of a river". FEMS Microbiol. Ecol. Vol. 54, pp. 3546, 2005.

[7]. APHA, AWWA, WEF, "Standard methods for the examination of water and waste water. 20th American Public Health Association, American Water Works Association", Water Environment Federation. 1992.

[8]. T.N. Joutey, W. Bahafid, H. Sayel, E.S. Abed, E.N. Ghachtouli, "Remediation of hexavalent chromium by consortia of indigenous bacteria from tannery waste-contaminated biotopes in Fez, Morocco". International Journal of Environmental Studies, Vol. 68, Issue., 6, pp. 901-912, 2011.

[9]. S.C. Paul, P. Jain, J. Mitra, S. Dutta, P. Bhattacharya, B. Bal, D. Bhattacharya, S.D. Gupta, S. Pal, "Induction of $\mathrm{Cr}$ (VI) reduction activity in an Anoxybacillus strain under heat stress: a biochemical and proteomic study". FEMS Microbiol Lett, Vol. 331, pp. 70-80, 2012.

[10]. A. Malik, R. Jaiswal, "Metal resistance in Pseudomonas strains isolated from soil treated with industrial wastewater", Journal of Microbiology \& Biotechnology, Vol. 16, pp.177-182, 2000.

[11]. J.G. Holt, N.R. Krieg, P.H.A. Sneath, J.T. Staley, S.T. Williams, "Bergey's Manual of determinative Bacteriology". $9^{\text {th }}$ ed. Lippioncott Williams and Wilkins, Baltimore, London, pp. 204209, 2000.

[12]. B.H. Joshi, K.G. Modi, "Screening and characterization of heavy metal resistant bacteria for its prospects in bioremediation of contaminated soil", Journal of Environmental Research And Development, Vol. 7, Issue., 4A, pp. 1531-1538, 2013.

[13]. Y.G. Liu, W.H. Xu, G.M. Zeng, X. Li, H. Gao, “Cr(VI) reduction by Bacillus sp. isolated from chromium landfill", Process Biochemistry, Vol. 41, pp. 1981-1986, 2006.

[14]. G. Biswas, R. Das, S.K. Kazy, "Chromium bioremediation by Alcaligenes faecalis strain $p-2$ newly isolated from tannery effluent", Journal of Environmental Research And Development. Vol. 9, Issue., 3A, pp. 840-848, 2015.

[15]. R. Bakiyaraj, L. Baskaran, L.A. Chidambaram, T. Mahakavi, M. Santhoshkumar. "Bioremediation of Chromium by Bacillus subtilis and Pseudomonas aeruginosa", Int. J. Curr. Microbiol. App. Sci, Vol. 3, Issue., 9, pp. 715-719, 2014.

[16]. S. Basu, M. Dasgupta, B. Chakraborty, "Removal of chromium (VI) by Bacillus subtilis isolated from East Calcutta wetlands, West Bengal, India", Int. J. biosci, biochem and bioinformatics, Vol. 4, Issue., 1, pp. 7-10, 2014. 
[17]. S. Dey, A.K. Paul, "Hexavalent chromium reduction by aerobic heterotrophic bacteria indigenous to chromite mine overburden", Brazilian Journal of Microbiology, Vol. 44, Issue., 1, pp. 307315, 2013.

[18]. V. Jyostna, G. Anuhya, U. Managamuri, K. Srinuvasulu and S. Poda, "Outcome of Cadmium on Aminergic System and Protective Function of Vitamin-C", International Journal of Scientific Research in Biological Sciences, Vol.5, Issue., 2, pp. 18-23, 2018.

[19]. U. Thacker, R. Parikh, Y. Shouche, D. Madamwar, "Reduction of chromate by cell-free extract of Brucella sp. Isolated from $\mathrm{Cr}(\mathrm{VI})$ contaminated sites", Bioresource Technology, Vol. 98, pp. 1541-1547, 2007.

[20]. S. Sultan, S. Hasnain, "Chromate reduction capability of a gram positive bacterium isolated from effluent of dying industry". Bull. Environ. Contam. Toxicol., Vol. 75, pp. 699-706, 2005.

[21]. G. Ozdemir, N. Ceyhan, T. Ozturk, F. Akirmak, T. Cosar, "Biosorption of chromium (VI), cadmium (II) and copper (II) by Pentoea sp. TEM18", Chem. Eng. J., Vol. 102, pp. 249-253, 2004.

\section{Author profiles-}

Ms Rachna Singh pursued B.Sc. from ASPG College, Mawana, Meerut, pursued M.Sc., M. Phil., from Microbiology Department, Chaudhary Charan Singh University, Meerut in 2006, 2008 and 2009. Currently pursuing Ph.D. from SOS in Microbiology, Jiwaji University, Gwalior. She has published 2 research

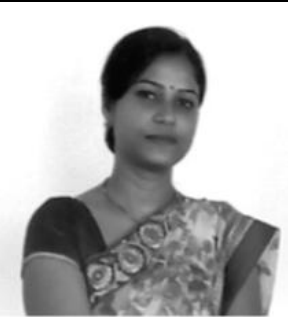

articles in reputed international journals including (SCI \& Web of Science). Her main work focuses on industrial and environmental science regarding and bioremediation. She has 2 years of teaching and 5 years of research experience.

Dr. Mahendra K. Gupta pursued M.Sc., M.Phil. and Ph.D. from Rani Durgavati University, Jabalpur MP. He is currently working as Professor of Botany in School of Studies in Botany and also holding the position as Head, School of Studies in Microbiology, Jiwaji University (Accredited 'A' grade by NAAC state University), Gwalior MP.

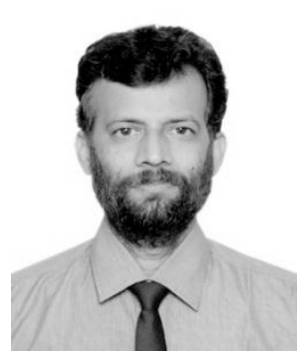
At present he is Chairman, Board of Studies in Botany and Microbiology and also involved in various Academic bodies as member in different Universities and Autonomous educational institution. He has awarded as Fellow of Indian Botanical Society (FBS) and Fellow of International Congress on Environmental Research (FICER) and also conferred the 'Scientist of the year Award-2014' and 'Eminent Scientist of the year award-2016' from Foundation for Science and Environment, Kolkata. He is a Life member of many scientific societies (more than 10) at National and International repute like Indian Science Congress Association, Indian Botanical Society, International Congress on Environmental Research, Mushroom Society of India etc. He has published more than 50 research papers in reputed international and national journals including Thomson Reuters (SCI \& Web of Science) and attended/ chaired session/ delivered invited talk in more than 100 national and international conferences. He has also edited/ authored 13 books in his credit. He has also organised about 20 national/ international seminars and workshops/ training programmes. His main research work focuses on Environmental Microbiology, Bioremediation and Biotechnology. He has more than 25 years of teaching and research experience. 